\title{
Effective Management of Local Budget Revenues and Expenditures in the Conditions of Modernization of the Economy
}

\author{
Musayeva Feruza Shohruxovna \\ Department of Finance, Tashkent Institute of Finance, 60A, Amir Temur street, 100000, Tashkent, Uzbekistan
}

\begin{abstract}
This article highlights the importance of local budgets in the implementation of economic and social functions of the state, first of all, in the redistribution of public funds and the development of social infrastructure.

Keywords: budget, government budget, local budget, Budget Code, Tax Code, social sphere, social protection

DOI: $10.7176 / \mathrm{EJBM} / 11-14-04$
\end{abstract}

Publication date:May $31^{\text {st }} 2019$

Public finance in the Republic of Uzbekistan and the state budget, which is an important part of it, are important in the modernization of the economy. The state budget forms the material and financial basis for the implementation of a number of social, economic, political, environmental and other functions of the state and enters into specific relationships with all aspects of the country's financial system, regulated by the budgetary financial legislation. Complete and effective implementation of the priorities of the Republic of Uzbekistan's development, sustainable and balanced economic development, robust place in world markets, ensuring consistent economic growth, enhancing the living standards and wellbeing of the people a thorough study of the mechanism of enforcement of the state budget is more timely than ever.

Local Budgets - budgets of local bodies of state authority and state administration.

In the socialist countries, local budgets are plans for the formation and use of the monetary resources required by local bodies of power for implementation of assigned functions. The plans are compiled on the basis of economic development plans. The system of local budgets of each socialist country is dependent on the state structure and is fashioned of principles of democratic centralism in economic management. Local budgets are ratified by local governing bodies and arean integral part of the statebudget of each country. In capitalist countries local budgets represent annual estimates of probable receipts and expenditures of local administrative bodies. They are confirmed by local bodies and are not included in the structure of state budgets (that is, formally they are kept separate). In actual fact, the rights of local administrative bodies, including budgetary rights, are determined by the acts of central governments. ${ }^{1}$

Budgetary relations as an economic category are a component of financial relations. The financial characteristics of the budget are first of all the kind of money relations that have emerged during the process of distribution, rather, redistribution of social product. Second, the budget is a fund aimed at the formation, distribution and use of centralized financial resources.

The state budget is a financial plan developed and approved by the relevant central (central or local) state administration body, which reflects the main expenses of the state, which are carried out on its functions, and the income required for their financing.

A budget system is a complex of interrelations between budgets of various levels and budget recipients, the principles of organization and budget formation, between them, and between budgets and budget recipients in the budget process.

In many cases, simplistically, when referring to the budget system, a set of budgets in the country is understood.

The budget system of this country can be two or three stages. In countries that are referred to as unitary states, the budget system can consist of two stages (central and local budgets), and in countries that are considered federative states, three stages (central budget, federal budgets and local budgets) .

The reform of the economy and the budgetary relations in the Republic of Uzbekistan is carried out in an evolutionary way, step by step, in interaction with other sectors and spheres of social life.

The state budget is the constituent part of the public finance system and the content of the State Budget is directly related to the socio-economic function and responsibilities of the state. The state budget is the main source of funding for the socio-economic policies of the state, the provision of social services and sectors. The state budget is of paramount importance in governance and promotion of the state budget, in ensuring social stability, and success in achieving priority development goals, as well as other economic instruments of the state. Effective implementation of these tasks will be ensured through elaboration and practical application of relevant mechanisms of the state budget.

Local budgets are a part of the state budget, which forms the provincial, district, city funds. Local budgets

\footnotetext{
${ }^{1}$ https://encyclopedia2.thefreedictionary.com/Local+Budgets
} 
come from local taxes and fees and payments. Local budgets are one of the financial sources of regional development. Local budgets are an integral part of the national budget for each country.

The first local budgets on the territory of Uzbekistan originated from the early 70s of the 19th century as the city and the regional budgets were established after the establishment of colonial rule in Central Asia. Later, district budget were established. These budgets were determined by the officials of the Central Office of the Turkestan General-Governorate of the Russian Federation, and were largely directed to the administration, police, and the judiciary.

Local budgets for the first time in Uzbekistan appeared in 1924-25. In the Republic of Uzbekistan among the revenue sources of local budgets, deductions from value added tax and excise tax are the leading ones. In addition, resources and other taxes (water use tax, environmental tax, infrastructure development tax, etc.) also participate in the formation of local budgets.

Implementation of targeted programs and activities for science, education, culture, health, physical culture and sports, social security, maintenance of local government, preservation of budgetary organizations, development of economic sectors is funded by the local budget at the expense of the legislation.

The socio-economic essence of local budgets is evident in its functions. The following can be mentioned:

$>$ forming of monetary funds that form the financial basis of local authorities;

$>$ redistribution and use of these funds between regional economic sectors and social spheres;

$>$ control over the financial and economic activity of enterprises, organizations and institutions subordination to local authorities.

Local budgets include the following budgets(Picture 1):

$>$ The budget of the Republic of Karakalpakstan - the republican budget of the Republic of Karakalpakstan and the budgets of districts and towns subordinate to the Republic;

$>$ The regional budget - the budget of the district and the budget of the districts and cities of the region;

$>$ The city budget, divided into districts - general budget and budgets of the districts of the city;

$>$ District budget (containing cities)

Local budgets are the main supporters of the state's policy on social protection of the population. Almost $100 \%$ of the population's social protection costs are financed by local budgets.

Local budgetary institutions serve as the medium for determining what local services will be provided and how they will be financed. Transparency of these institutions is critical to ensuring that local governments are responsive to citizen preferences; that they deliver local services efficiently, equitably, and with integrity; and that the electorate can hold them accountable for their service delivery performance. Open and transparent local budgeting is thus viewed as critical to the integrity of the local public sector and to citizens' trust in government. The socio-economic essence of local budgets is expressed in the following functions:

$>$ forming of monetary funds that form the financial basis of local authorities

$>$ redistribution and use of these funds between regional economic sectors and social spheres;

$>$ control over the financial and economic activity of enterprises, organizations and institutions subordination to local authorities.

The further increase of the role of local budgets is undoubtedly an important factor in raising the effectiveness of fiscal policy of the government, in which efforts are being made to further support them.

Formation and budget expenditures are approved by the provincial, district, city governing bodies.

Local budgets provide financial resources for socio-economic development of the regions.

After gaining independence, a great deal of emphasis was placed on consolidating the legal framework to harmonize the work and experience of the full budget system with world experience in this field.

In the transition to a market economy, the budget revenues are based on the taxation of the legal entities and individuals in accordance with the legislation and the non-tax payments on the basis of the development of various forms of ownership and the development of a multidisciplinary economy.

Incomes of the regional, district, city budget:

$>$ Taxes and levies deducted in accordance with the laws of the Republic of Uzbekistan;

$>$ receipts from the sale or renting property of the region, district and city;

$>$ a part of the concealed or deductible revenues revealed during inspections of enterprises, institutions and organizations that are the property of the region, area, city in the cases provided by the legislation;

$>$ Other receipts under the laws of the Republic of Uzbekistan.

Regional, district, city Council of People's Deputies incomes:

$>$ voluntary contributions and donations of citizens, enterprises, institutions and organizations

$>$ some types of fines imposed under the laws of the Republic of Uzbekistan;

$>$ off-budget funds, which may include extra-budgetary funds.

Extra-budgetary funds remain in special bank accounts, can not be withdrawn, they are spent according to the decision of the Council of People's Deputies and governor.

While the socio-economic essence of local budgets is evident in its functions, it sets out a number of tasks 
that are primarily linked to the expansion and strengthening of local budgets' revenue base in socio-economic development of the regions. Even in the conditions of modernization of the economy, the lack of local budgets' own revenues, still requiring high budgets, requires the proper management of local budgets. In this respect, the competencies of financial authorities play an important role in managing local budgets.

We know that the budget revenues are the funds received in the budgetary system budget in the nondiscriminatory and non-repayable manner defined by the legislation. Budget revenues include tax and non-tax revenues.

The revenue base of local budgets is directly linked to the national income generated in the regions, such as the level of development of production, the constant and regular revenue generation gains in the interest of local government revenue growth. First of all, it is necessary to note that internal revenues of the local budget increase incomes, development of production in the regions, the privatization of state property in the implementation of economic reforms, particularly in the field of economic reforms in the regions, the creation of various forms of ownership, development is crucial. Strengthening the revenue base of local budgets is directly related to the ongoing reforms in agriculture.

The structure of local budgets of the Republic of Uzbekistan ${ }^{1}$

Picture 1

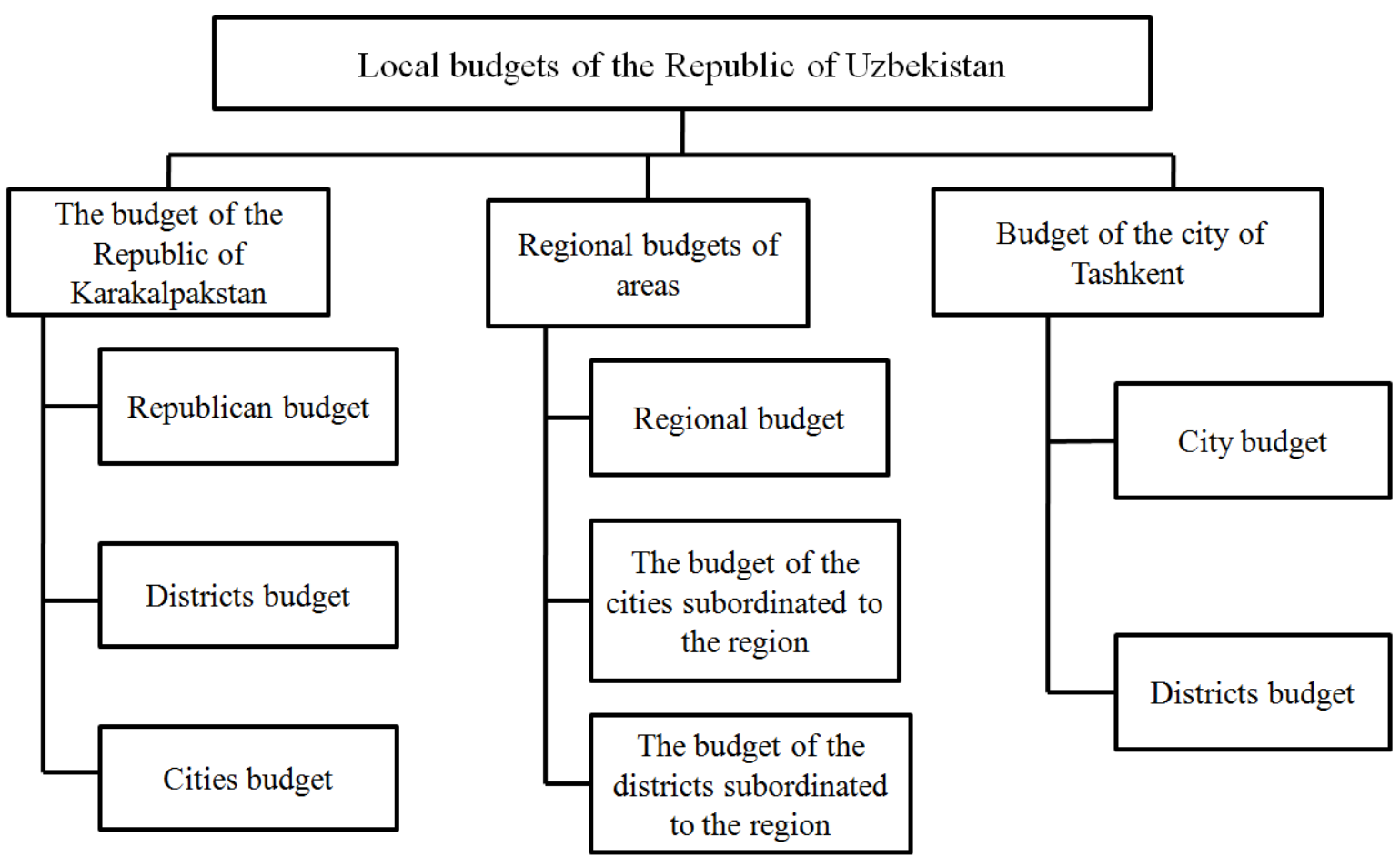

\footnotetext{
${ }^{1}$ Information Ministry of Finance of the Republic of Uzbekistan
} 
The Role of Local Budgets

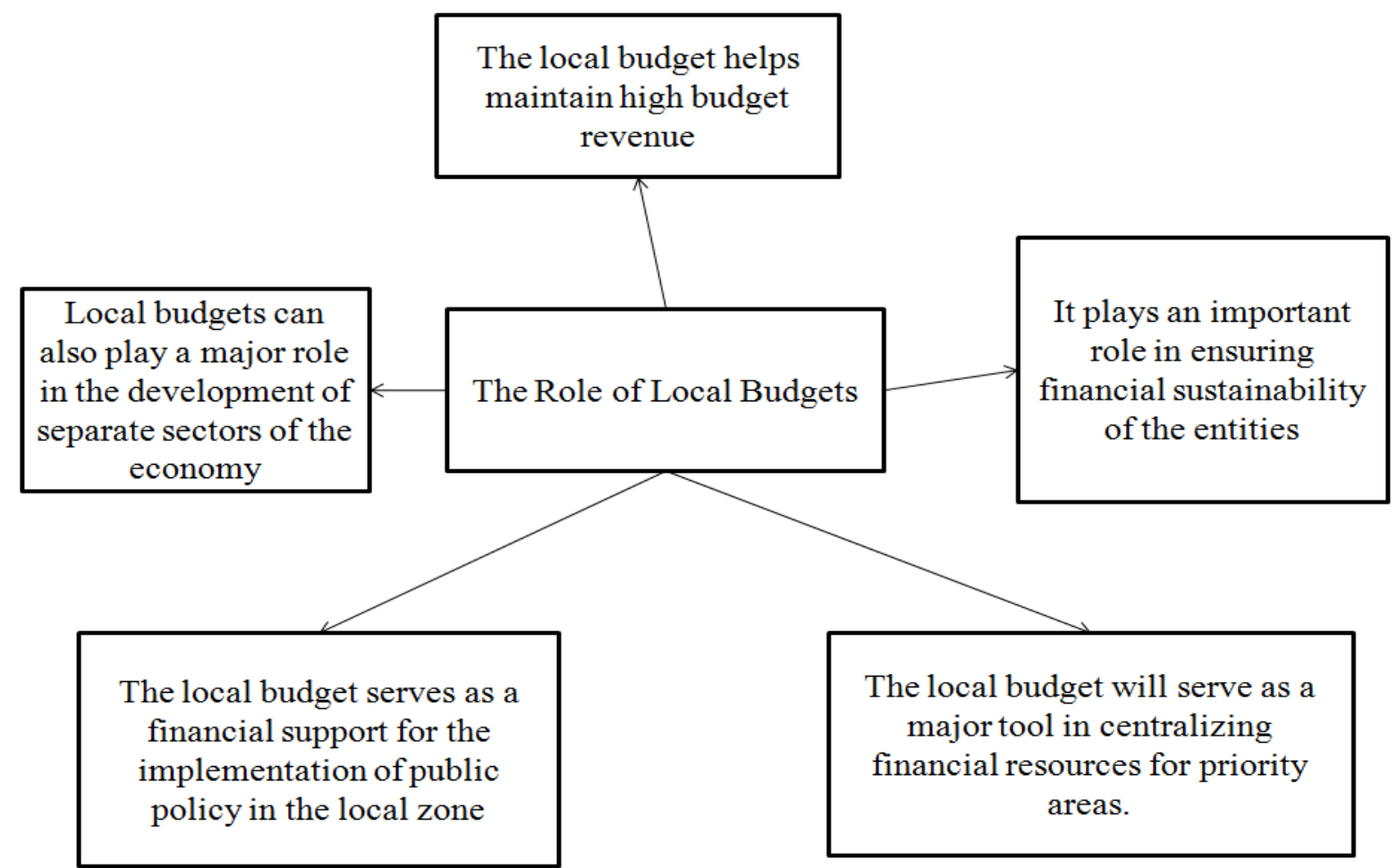

Functions of the local budget ${ }^{1}$

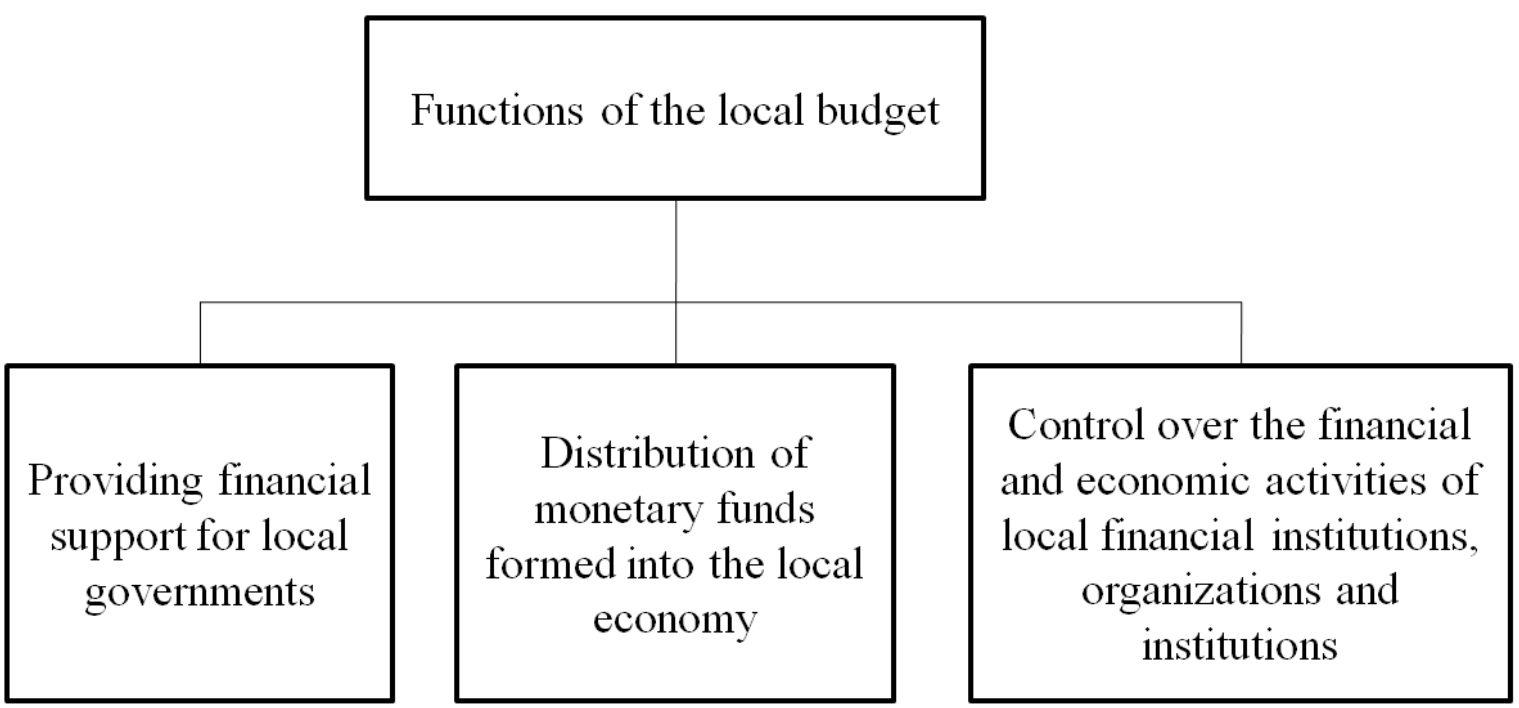

The ratio of local budget revenues depends on the responsibilities of the local authorities, the ability to collect local taxes and fees, and the ability of higher state authorities to provide financial assistance to the regions, the level of economic development of the regions, and fiscal-budget policy implemented by the state directly. . According to the Tax Code of the Republic of Uzbekistan, taxes are levied on the national taxes and local taxes and fees. Generally, the local budget revenues are divided into two types:

$>$ Incomes attached to local budgets;

$>$ Regulatory income of local budgets.

Article 52 of the Budget Code of the Republic of Uzbekistan provides the sources of revenues for the budget of the Republic of Karakalpakstan, local budgets of provinces and the city of Tashkent.

Incomes of the budget of the Republic of Karakalpakstan, local budgets of provinces and the city of Tashkent:

1) National taxes in accordance with the established standards, including:

\footnotetext{
${ }^{1}$ Sirojiddinova Z.X. "Budget system of the Republic of Uzbekistan" textbook, 2010y
} 
$>$ profit tax for legal entities;

$>$ single tax payment;

$>$ income tax on physical entities;

$>$ fixed tax on certain types of entrepreneurial activity;

$>$ value added tax;

$>$ the tax on the use of subsoil;

$>$ water use tax;

2) local taxes and other mandatory payments, including:

$>$ property tax;

$>$ land tax;

$>$ single land tax;

$>$ fees, the right to retail trade in certain types of goods, and the provision of certain types of services;

3) legal entities and individuals, as well as non-returnable money from foreign countries;

4) incomes from markets;

5) other revenues. Revenues from the sale of property transferred to the state revenue of other incomes, revenues received from the allocation, use and sale of state assets, the state in which they are directed to the budget of the Republic of Karakalpakstan, local budgets of provinces and the city of Tashkent fees, levies, penalties and fines, land plots, property transferred to state-owned property under the right of inheritance, and treasury bills that are subject to state-owned dividends (income) on the share of state authority bodies and other incomes according to the legislation.

Subvents, transferable income, subsidies and targeted social transfers from the national budget of the Republic of Uzbekistan are the incomes of the Republic's budget of the Republic of Karakalpakstan, regional budgets of provinces and the city budget of Tashkent city.

Water tax, fixed tax on certain types of entrepreneurial activity, excise tax on beer produced in the Republic of Uzbekistan, are transferred to the budget of the Republic of Karakalpakstan, local budgets of provinces and Tashkent city.

Local taxes and other mandatory payments can be redistributed between the Republic of Karakalpakstan budget, regional budget of provinces, city budget of Tashkent city and budgets of districts and cities in accordance with approved norms.

The tax system is a very complex economic process, which is a combination of taxes and fees, the interconnection and integrity of taxation and taxation mechanisms. Taxes also include national and local taxes, depending on the budget. National taxes are monetary funds that come to the state budget and serve the national scale.

However, not all of these taxes are levied in the state or the national budget, some are left in the hands of local authorities, based on the level of economic and social development of the regions.

Domestic taxes are an important part of the tax system, which is largely abandoned in local budgets to fulfill local government functions and responsibilities.

According to the Tax Code of the Republic of Uzbekistan, local taxes are as follows:

$>$ property tax;

$>$ land tax;

$>$ improvement and social infrastructure development tax;

$>$ tax on motor vehicles for gasoline, diesel fuel and gas from individuals;

$>$ the fee for the right to trade, as well as the fee for a license for the sale of certain types of goods;

$>$ fees for legal entities as well as individuals for business registration.

The consolidation of the revenue base of local budgets is one of the important directions of the inter-budgetary reconciliation. In order to cover less of the local budgets incomes generated by local taxes and non-tax revenues in the republic, the formation of the major part of revenues of the local budgets through inter-budgetary regulation. These types of income are referred to as regulatory revenues (Figure 1). These incomes are generated through the relationships between the budgets of the budget system. 


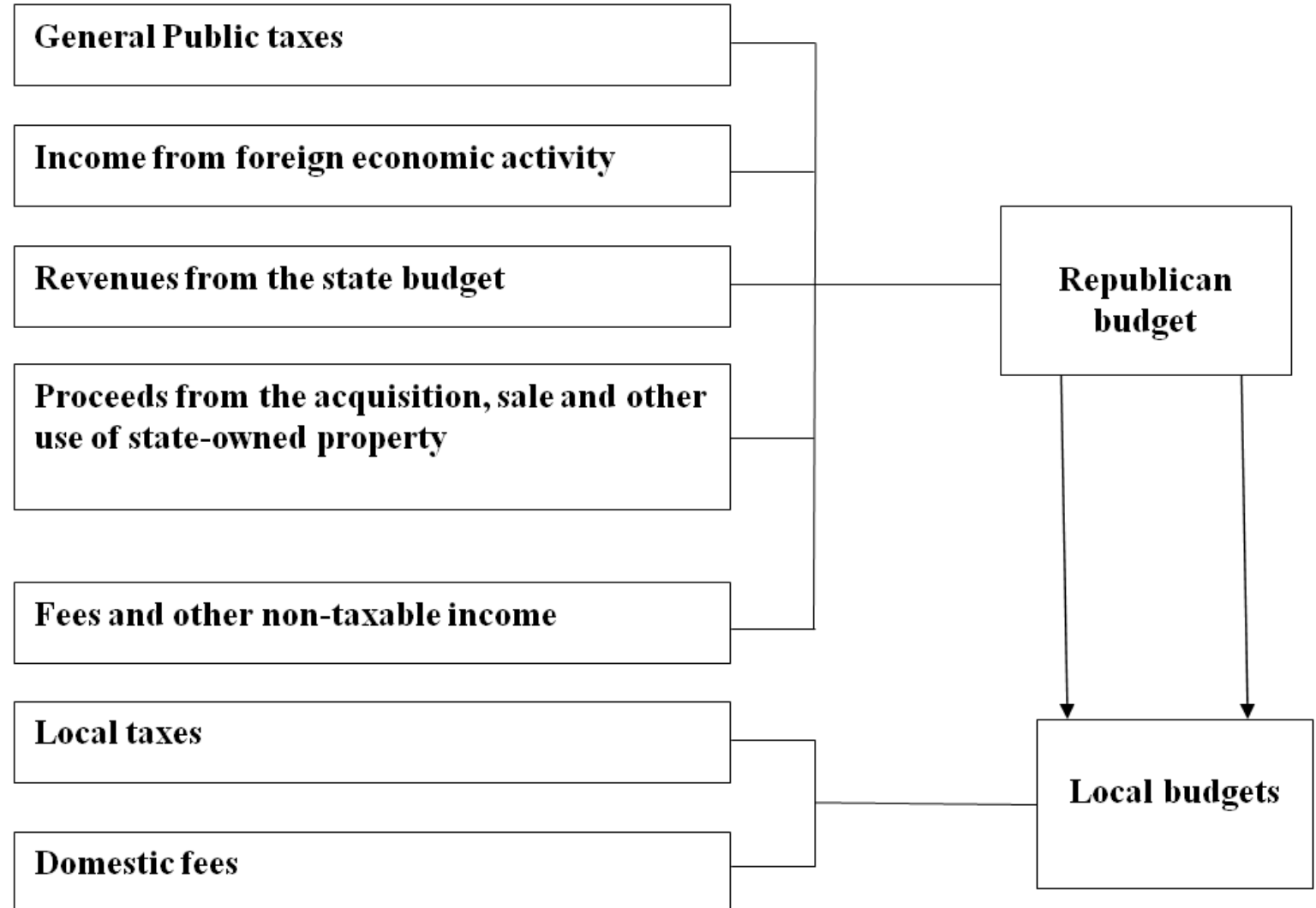

In the process of diversification of the economy, the socio-economic situation of the regions, their level of development, and the investment climate play a crucial role. The role of regional development in the national economy is, in our view, the following: proportionate development of regions - macroeconomic stability and economic growth; the territorial disparity of the national economy can provide growth of the gross domestic product of the country by an additional 1-3\%; availability of opportunity to deal with existing problems in the faster territory than in the development of entrepreneurship and increasing the competitiveness of the economy; the impact of changes in regional economies on direct macroeconomic processes; become a regional participant of globalization and interregional integration processes; The role of regions in forming a competitive environment is high. All expenses of the budget system are distributed between different budgets, which means that this expenditure may be included in a certain budget.

According to Article 71 of the Budget Code of the Republic of Uzbekistan the following expenses are made from the republican budget of the Republic of Karakalpakstan, regional budgets of provinces and the city budget of Tashkent city:

$>$ social sphere and social support expenditures

$>$ economy expenditures

$>$ expenditures for financing centralized investments, which are the customers of the Council of Ministers of the Republic of Karakalpakstan, regional and Tashkent city khokimiyats;

$>$ local government authorities and administration

$>$ expenditures on formation of reserve funds of the Republic budget of the Republic of Karakalpakstan, regional budgets of provinces and city budget of Tashkent city

$>$ expenses incurred to legal and physical persons in connection with the seizure of land parcels for state or public needs;

$>$ expenses of organizations and arrangements funded by the republican budget of the Republic of Karakalpakstan, regional budgets of provinces and the city budget of Tashkent city.

\footnotetext{
${ }^{1}$ Based on the data of the Tax Code of the Republic of Uzbekistan
} 


\section{Local budget expenditures of Tashkent city ${ }^{1}$}

\begin{tabular}{|c|l|c|c|c|}
\hline № & \multicolumn{1}{|c|}{ Expenses } & $\begin{array}{c}2017 \mathrm{y} \\
\text { (thousand } \\
\text { soums) }\end{array}$ & $\begin{array}{c}2018 \mathrm{y} \\
\text { (thousand } \\
\text { soums) }\end{array}$ & $\begin{array}{c}2019 \mathrm{y} \\
\text { (thousand } \\
\text { soums) }\end{array}$ \\
\hline 1 & Expenditure on education & 808348000 & 924242682 & 1441525577 \\
\hline 2 & Health Care Costs & 528448000 & 598949621 & 843930750 \\
\hline 3 & Costs of training specialists & 8386000 & 204104 & 240071 \\
\hline 4 & Culture and Sports & 23994000 & 52201925 & 94624114 \\
\hline 5 & Science expenses & 670345 & 1459120 & 2829650 \\
\hline 6 & $\begin{array}{l}\text { Retirement benefits for families with children and } \\
\text { low income families }\end{array}$ & 2423000 & 3632190 & 3602389 \\
\hline 7 & Social protection of Chernobyl catastrophes & 4733 & 5049 & 5907 \\
\hline 8 & Costs of state awards & 2254000 & 2522096 & 3441543 \\
\hline 9 & Social Skills Centers & 1290000 & 1483652 & 1746882 \\
\hline 10 & Costs for the economy & 274847000 & 389931290 & 411523447 \\
\hline & Total costs & 2499125228 & 2378949305 & 3236227699 \\
\hline
\end{tabular}

The table shows that in 2017, the local budget expenditures for the city of Tashkent amounted to $2,499,125,228,000$ soums. In 2018 total expenditures of the city budget amounted to 2,377,949,305 thousand soms. In 2019 total expenditures of the city budget are planned to make 3236227699 thousand soums.

In the city of Tashkent in 2017-2019 the share of social expenditures in total expenditures has increased. The main reason for this is that, in the first years of independence, the social sphere has a priority, and that this sector is far behind the production, which is partly due to its position.

Funding for education, healthcare, culture and sports, and social security, which is vital to human development, is funded mainly from local budgets.

According to the data of the table, the most part of the budget expenditures is directed to the sphere of education: in 2017 808, 348, 000 soums were allocated for the sphere of education, which accounted for $58 \%$ of the total expenditure on social sphere and social protection of the population. In 2018, 924242682 thousand soums were allocated, which is $58 \%$ of the total expenditures on the social sphere and social protection of the population. In order to adapt the education system to world standards, to ensure the qualitative compliance of the prepared specialists to the education sphere, it is planned to allocate 1441525577 thousand soums to the education sphere in 2019 , which will cover $60 \%$ of all expenses of social sphere and social protection of the population.

One of the most important functions of the state is the social function of the state. When we say the social policy of the state, we understand the sum of measures undertaken by the state to create a stable and high standard of living for the population to fulfill the social protection system. Practice shows that the social policy of the state had specific features at different times, and the results of that policy were diverse. But in spite of the characteristics of social policy, we can distinguish between the most basic trends. This relates to:

1. The distribution of material and spiritual wealth should be carried out for that purpose to ensure social justice in society.

2. Demographic policy should be made to ensure that labor resources are rationally used.

3. The main task of the social sphere of the state for the formation of the rational social structure of the society is the organization of income of the population through various sources.

Priorities for the development of the social sphere include:

- Gradual increase of salaries and wages, pensions and social allowances;

- Effective methods of increasing the employment of the population;

- Providing the population with cheap and modern homes;

- Improving Living Conditions of the Population;

- Social Infrastructure Modernization;

- Social protection and healthcare system;

- Development of education and science;

- Improve the state of youth policy.

One of the most important directions of social policy of the state is the definition of social actions of the state, their systematization and classification. The first stage of the systematization of the state social policy is the classification of relevant measures into systemic categories and their order, which allows to define the fundamental character of the state social policy. Such classifications are based on a set of criteria.

There are four main criteria that can be used to analyze the state's social policies:

$>$ the nature of the mechanisms used to implement social policies;

\footnotetext{
${ }^{1}$ Based on decision-making data on the parameters of the local budget
} 
$>$ areas of social policy;

$>$ users of social services; social policy

$>$ targets.

Every year, a considerable part of the budget is mobilized to fund social cultural events and social protection of the population. These funds are for the state:

$>$ development of public education spheres;

$>$ science and culture development;

$>$ meeting the minimal needs of the population for medical services;

$>$ social protection of the population;

$>$ increasing the level of social security.

With increasing market relations, the role of social spheres is increasing through local budgets. At the moment, the task of increasing the effectiveness of the use of funds allocated from the local budget, the active involvement of extra-budgetary resources, the working capital of the social sphere, and the cash income of the citizens have been prioritized.

The role of local budgets in the state budget system is a financial basis for the organization and composition of revenue of local budgets.

Local budgets play an important role in the implementation of the national economic and social tasks, first of all, in the allocation of public funds and the development of social infrastructure.

Implementation of policies related to social protection by the state requires substantial financial and financial resources, and these important tasks are entrusted to local authorities. Funding for social protection measures is primarily funded by local budgets.

In recent years, the implementation of measures on the main priorities of economic reform has positively impacted the development of social sector and improving the basic human development indicators. In the implementation of these measures, the social functions of the state budget are particularly evident. Today, the goals and objectives of this social policy have not been changed; on the contrary, the scope and methods of state social policy are being further enhanced.

Studying foreign experience on increasing the role of local budgets in the development of social sphere is crucial in the process of reforms being undertaken in Uzbekistan in the transition to a market economy. This is because the outcome of the reforms in budgetary sphere is to finance and develop social spheres by increasing the role of local budgets in the budget process.

Independent economic policy that meets the interests of the people is an objective necessity for free development of any state. Building a market economy to meet the needs of members of the community is the core of state policy. Everyone or any social group, the social interests of the nation, always reflects on the relationship of the social system that satisfies its social needs.

\section{REFERENCES}

1. Budget Code of the Republic of Uzbekistan

2. Nurmukhamedova B.I., Hamdamov Sh.K. "State budget", educational-methodical complex

3. National Encyclopedia of Uzbekistan. The first volume. Tashkent, 2000

4. LOCAL BUDGETING, edited by ANWAR SHAH, THE WORLD BANK Washington, D.C., 2007y

5. Vahobov A., Jumaev N., Burkhanov U. International Finance Relations. -T .: East, 2003. -400 p.

6. Juraev A.S. Effective ways of formation of state budget revenues.Monograph. "Fan" publisher. 2004

7. Haydarov M. The treasury system of execution of the state budget. Educational manual. T .: Economy and Finance, 2010.

8. Qosimova G.A. Establishment and execution of local budgets. Educational manual. T .: "Science and Technology" 2007.

9. http://www.gov.uz

10. https://encyclopedia2.thefreedictionary.com/Local+Budgets

11. http://www.tfi.uz

12. http://www.lex.uz 